\title{
Effect of nano-sized, elemental selenium supplement on the proteome of chicken liver
}

\author{
G. Gulyas ${ }^{1}$, E. Csosz ${ }^{2}$, J. Prokisch ${ }^{1}$, A. Javor ${ }^{1}$, M. Mezes ${ }^{3}$, M. Erdelyi ${ }^{3}$, K. Balogh ${ }^{3}$, T. Janaky ${ }^{4}$, Z. Szabo ${ }^{4}$, \\ A. Simon ${ }^{1}$ and L. Czegledi ${ }^{1}$ \\ 1 Department of Animal Science, University of Debrecen, Debrecen, Hungary \\ 2 Department of Biochemistry and Molecular Biology, Faculty of Medicine, University of Debrecen, Debrecen, Hungary \\ 3 Department of Nutrition, Szent Istvan University, Godollo, Hungary, and \\ 4 Department of Medical Chemistry, Faculty of Medicine, University of Szeged, Szeged, Hungary
}

\section{Summary}

The nano-sized (100-500 nm) selenium has higher bioavailability and relatively lower toxicity compared to other selenium forms. The objective of the present study was to compare liver proteome profiles of broiler chicken fed with control diet without Se supplementation and diet supplemented with nano-Se with $4.25 \mathrm{mg} / \mathrm{kg}$ DM. Differential proteome analyses were performed by two-dimensional gel electrophoresis (2D-PAGE) followed by tryptic digestion and protein identification by liquid chromatography-mass spectrometry (LC-MS). Seven hundred and eight spots were detected, and 18 protein spots showed significant difference in their intensity $(p<0.05)$ between the two groups. In response to nano-Se supplementation, the expression of 8 proteins was higher, and 5 proteins were lower in nano-Se supplemented group compared to control group. The functions of the differentially expressed proteins indicate that the high dose of selenium supplementation induced a dietary stress. Selenium supplementation may influence the metabolism of fatty acids and carbohydrates and antioxidant system, and increase the quantity of cytoskeletal actin and the expression of actin regulatory protein as well.

Keywords selenium, chicken, liver, protein expression, Two-Dimensional Polyacrylamide Gel Electrophoresis

Correspondence L. Czegledi, Institute of Animal Science, Biotechnology and Nature Conservation, University of Debrecen, 138 Boszormenyi Street, 4032 Debrecen, Hungary. Tel: +3652508444; Fax: +3652486285; E-mail: czegledi@agr.unideb.hu

Received: 13 June 2015; accepted: 24 November 2015

\section{Introduction}

Selenium is one of the essential trace elements for life processes (Köhrle, 2004). The biological significance of Se was recognized only in 1973, as a component of the glutathione peroxidase (GPx). This enzyme has an important role in intracellular defence mechanisms against oxidative damage because it prevents the formation of reactive oxygen species (Rotruck et al., 1973). Glutathione peroxidase is a selenoprotein which protects cells and membranes from oxidative damage by destroying hydrogen peroxide and hydroperoxides (Watanabe et al., 1997). Selenium is an important component of several other selenoproteins with essential biological functions (Van Cauwenbergh et al., 2004). Even though the functional roles of these selenoproteins are not fully understood, there is an increasing evidence that these selenoproteins and other Se-containing metabolites are important in immune function and reduce the risk of cancer (Tinggi, 2003). Selenium-enriched food can increase the human selenium status, and optimal selenium intake contributes to human health (Fisinin et al., 2009). The selenium status of chicken has effect on survival, growth performance, resistance to diseases, fertility, shelf life of eggs and hatchability (Pappas et al., 2006; Surai, 2006). Earlier, inorganic selenium compound (sodium selenite) has been incorporated into animal diets, but nowadays organic forms of Se (i.e. selenomethionin, selenocysteine or selenium-enriched yeast) are preferred (Payne and Southern, 2005). Chen and co-workers demonstrated that different selenium forms (inorganic and organic) had no clear effect on the production traits of broilers, but influenced the resistance against oxidative stress (Chen et al., 2014).

Oremland et al. (2004) presented a biological way to produce nanospheres elemental selenium by selenium-reducing anaerobe bacteria. Eszenyi et al. (2011) used lactic acid bacteria to reduce the selenite in toxic concentration into nano-sized elemental selenium spheres with high purity. This procedure seems to be more effective than chemical synthesis. Materi- 
als at the nanometers dimension hold promise for application in medicine and nutrition. Plants and several microorganisms, including bacteria and fungi, can synthesize nanoparticles in their metabolic pathways. Nano-sized selenium has higher bioavailability and relatively low toxicity compared to other selenium forms (Wang et al., 2007). There is a lack of information about the role of increased Se content of feed on liver proteome; thus, the objective of the present study was to compare liver protein profiles of broilers fed with control diet and feed supplemented with $4.25 \mathrm{mg} / \mathrm{kg}$ DM nano-Se.

\section{Materials and methods}

Animals and sampling

Probiotic lactic acid bacteria were applied for the production of elemental selenium nanospheres (100$500 \mathrm{~nm}$ ) by fermentation (patent Prokisch and Zommara, 2010). Twelve Cobb 500 broiler chickens were used in the proteomics experiment. Birds were kept at conventional housing system, and they had ad libitum access to feed and water. The control group $(n=6)$ was fed with a diet without Se supplementation, and the nano-Se supplemented group $(n=6)$ was fed with a diet supplemented with $4.25 \mathrm{mg} / \mathrm{kg}$ nano-Se for 42 days. Chickens were sacrificed on day 42 of the trial, and livers were removed. From each liver, three replicate samples (about $2 \mathrm{~g} /$ replicate sample) were cut and snap frozen in liquid nitrogen within 20 min after slaughter and then kept at $-80{ }^{\circ} \mathrm{C}$ until the subsequent analyses. The three replicates of liver samples were pooled before protein isolation. The selenium content of liver was $185 \pm 80 \mu \mathrm{g} / \mathrm{kg}$ and $890 \pm 46 \mathrm{l} \mu \mathrm{g} / \mathrm{kg}$ (mean \pm SD) in control and nano-Se supplemented groups, respectively.

\section{Ethical issues}

The experiment was carried out according to the regulations of the Hungarian Animal Protection Act, in compliance with the EU rules. The experimental protocol was authorized by the Food Chain Safety and Animal Health Directorate of the Pest County Agricultural Office, under permission number XIV-1-001/ $1880-5 / 2011$.

\section{Extraction of proteins}

Protein samples were prepared from chicken liver tissue as follows: tissue samples were placed in liquid nitrogen and ground thoroughly to a very fine powder with a mortar and pestle. The tissue powder (100 mg) was transferred to sterile tubes, containing $1 \mathrm{ml}$ of lysis buffer $(8.5 \mathrm{~m}$ urea, $2 \mathrm{~m}$ thiourea, $4 \%(\mathrm{w} / \mathrm{v})$ CHAPS, 60 mm DTT, $0.2 \%$ (v/v) Bio-Lyte 4/6 and 6/8 ampholyte at a ratio of $1: 2$ ) and $80 \mu$ proteinase inhibitor cocktail (Promega). The mixture was incubated for $60 \mathrm{~min}$ at room temperature with occasional vortexing and centrifuged at $15000 \mathrm{~g}$ for $40 \mathrm{~min}$ at room temperature. The supernatant was collected and stored at $-80^{\circ} \mathrm{C}$ until further analysis. The protein concentration was determined using RC DC protein assay kit (Bio-Rad, Hercules, CA, USA) with bovine serum albumin (BSA) as standard.

\section{Two-Dimensional Polyacrylamide Gel Electrophoresis (2D-PAGE)}

For the first dimension (isoelectric focusing) of twodimensional gel electrophoresis, 7-cm immobilized $\mathrm{pH}$ gradient (IPG) strips ( $\mathrm{pH}$ 5-8, linear, Bio-Rad) were rehydrated by passive rehydration using samples dissolved in $125 \mu \mathrm{l}$ rehydration buffer $(2 \mathrm{~m}$ thiourea, $8 \mathrm{M}$ urea, 2\% CHAPS, $15 \mathrm{mg} / \mathrm{ml}$ DeStreak reagent, $0.2 \%$ $(\mathrm{v} / \mathrm{v})$ Bio-Lyte $4 / 6$ and $6 / 8$ ampholyte at a ratio of $1: 2$, $0.002 \%(\mathrm{w} / \mathrm{v})$ bromphenol blue) for $15 \mathrm{~h}$ at room temperature. $150 \mu \mathrm{g}$ of protein was loaded, and the isoelectric focusing was conducted in Protean IEF Cell (Bio-Rad). Low voltage $(250 \mathrm{~V})$ was applied for $15 \mathrm{~min}$, and then, the voltage was gradually increased to $4000 \mathrm{~V}$ over $2.5 \mathrm{~h}$ and maintained at that level until a total of $20000 \mathrm{Vh}$. Focused IPG strips were equilibrated for $10 \mathrm{~min}$ in $6 \mathrm{~m}$ urea, 20\% (v/v) glycerol, $2 \%$ (w/v) SDS, $50 \mathrm{~mm}$ Tris pH 8.8 and $2 \%(\mathrm{w} / \mathrm{v})$ DTT, and then for an additional $10 \mathrm{~min}$ in the same buffer except that DTT was replaced by $2.5 \%(\mathrm{w} / \mathrm{v})$ iodoacetamide. After equilibration, proteins were separated in the second dimension using OmniPAGE Mini (Cleaver Scientific) vertical electrophoresis system. Second dimension was performed on $100 \times 100 \mathrm{~mm}, 13 \%$ polyacrylamide gels (37.5:1 acrylamide:bis-acrylamide ratio). The gels were run by applying $80 \mathrm{~V}$ in the first $10 \mathrm{~min}$ and then $170 \mathrm{~V}$ until the bromphenol blue dye marker reached the end of the gels. A cooling system provided constant $20^{\circ} \mathrm{C}$ running temperature. Polyacrylamide gels were stained with colloidal coomassie G-250 (Thermo Scientific) (Dyballa and Metzger, 2009). 2D-PAGE analysis was carried out in three replicates of each biologically independent sample; thus 18 gels per group, a total of 36 gels were analysed.

\section{Image analysis}

Gels images were recorded using PharosFX Plus (BioRad) scanner, and the image analysis was performed 
using Delta2D software (Decodon $^{\mathrm{TM}} \mathrm{GmbH}$, Germany). For gel analysis, all gels within a group were warped to a reference gel. A master gel was created by fusing all images using union fusion. Every spot on each gel was quantified and normalized according to the total intensity of all spots in each gel. Student's $t$-test was performed to assess the statistical significance of differentially expressed proteins at 95\% confidence level ( $t$-test; $\mathrm{p}<0.05$ ). For subsequent mass spectrometric analysis significant spot coordinates were transferred to a Coomassie-stained preparative gel for spot picking.

\section{Protein identification}

The protein spots of interest were cut out from the Coomassie-stained gels and digested by trypsin using the in-gel digestion protocol as described by Szabo and co-workers (Szabo et al., 2012). Briefly, excised gel spots were cut into small pieces and destained in $25 \mathrm{~mm} \mathrm{NH}_{4} \mathrm{HCO}_{3}$ and 50\% acetonitrile, and dehydrated with acetonitrile and dried. Then, the gel pieces were rehydrated in $12.5 \mathrm{ng} / \mu \mathrm{l}$ trypsin (Promega, Madison, WI, USA) solution (in $25 \mathrm{~mm} \mathrm{NH}_{4} \mathrm{HCO}_{3}$ ) and incubated overnight at $37{ }^{\circ} \mathrm{C}$. Peptides were extracted with 5\% formic acid and twice with $60 \%$ acetonitrile in $1 \%$ formic acid. Samples were concentrated with vacuum centrifugation and analysed by LC/MS on an Eldex MicroPro HPLC coupled with a Thermo LCQ Fleet ion trap mass spectrometer. The samples (5- $\mu$ l full loop injection) were initially transferred to the precolumn with $3 \% \mathrm{~B}$ eluent at a flow rate of $12 \mu \mathrm{l} / \mathrm{min}$ for $5 \mathrm{~min}$. The column was eluted with a linear gradient of $3-40 \%$ B over $35 \mathrm{~min}$. Mobile phase A consisted of $0.1 \%$ formic acid in water, while mobile phase B was $0.1 \%$ formic acid in acetonitrile. Separation was performed on an inhouse-made column (75 $\mu \mathrm{m}$ ID * $90 \mathrm{~mm}$ l column with $3 \mu \mathrm{m}$ particle size, Magic C18AQ packing from Bruker) with $\sim 400 \mathrm{nl} / \mathrm{min}$ flow rate. The mass spectrometer was operated in positive ion mode selecting peptide precursors from mass range m/z 450-1200 in triple play mode: the three most abundant ions from each full scan were selected for zoom scan followed by MS/MS scan of multiply charged precursor ions with the normalized collision energy value 35 (AGC and max ion time values: full scan: 10 000, 40 ms; zoom scan: 100, $80 \mathrm{~ms}$ and MSn scan: 50 000, $300 \mathrm{~ms}$, respectively).

All acquired data were processed by the MATRIXSCIENCE MAScot Distiller software (v2.4.3.3) using default settings for LCQ-Fleet data. Database search was performed using Маsсот 2.2 (Matrix Science,
London, UK) which was set up to search Uniprot Gallus gallus proteome (UP000000539) database (2015.01.09 version, 17656 entries) assuming the digestion enzyme trypsin, allowing 2 missed cleavage sites. The data were searched with 1 Da fragment and 0.6 Da parent ion mass tolerances. Oxidation of methionine and carbamidomethylation of cysteine were specified as variable and fixed modifications, respectively.

SCAFFOLD (version Scaffold 3.65, Proteome Software Inc, Portland, OR, USA) was used to validate MS/MSbased peptide and protein identifications. Protein identifications were accepted if they could be established at greater than $95.0 \%$ probability and contained at least two identified peptides. Protein probabilities were assigned by the Protein Prophet algorithm. Proteins that contained similar peptides and could not be differentiated based on MS/MS analysis alone were grouped to satisfy the principles of parsimony, and in these cases grouped accession numbers are listed.

\section{Results}

To examine the liver, protein profile changes as a response to nano-Se supplementation liver samples were analysed by two-dimensional electrophoresis followed by mass spectrometric protein identification. Approximately 708 spots were detected on each polyacrylamide gel (gels of control and nano-Se supplemented group as well). Eighteen protein spots showed significant difference in the intensity $(p<0.05)$ between the two groups, and 13 proteins were identified successfully by mass spectrometry (Fig. 1, Table 1).

\section{Up-regulated proteins in the nano-Se supplemented group}

The intensity of eight spots was higher in the nano-Se supplemented group compared to control group (Fig. 2). Protein spot 160 was identified as 'Uncharacterized protein' in the Uniprot database, but based on Blast search, this protein belongs to aldehyde dehydrogenase family, and it shows sequence homology with alpha-aminoadipic semialdehyde dehydrogenase in cattle. This is a multifunctional enzyme having protective functions: transforms betaine aldehyde to betaine, and metabolizes lipid peroxidation-derived aldehydes protecting cells against oxidative stress (Fong et al., 2006; Brocker et al., 2010). Spot 160 had a 2.3-fold higher expression in the nano-Se supplemented group compared to the control group. 
(a)

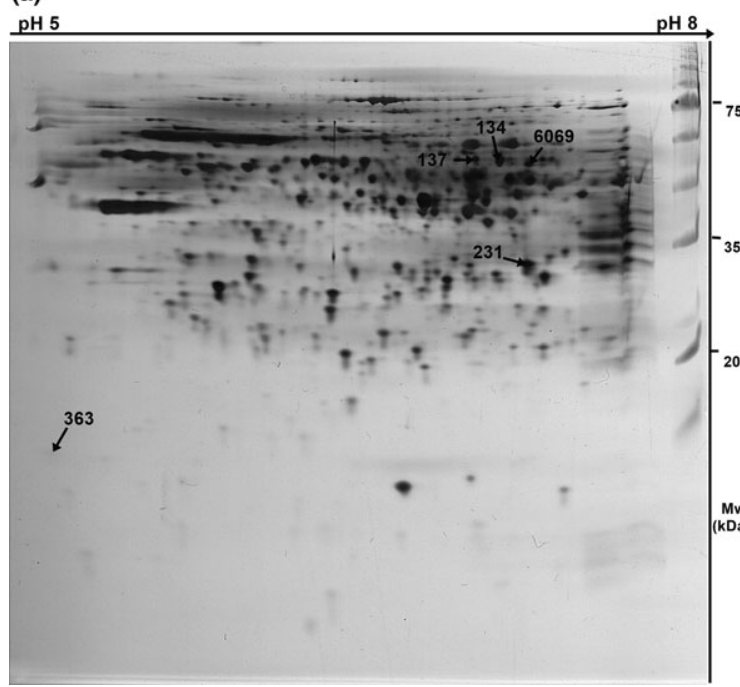

(b)

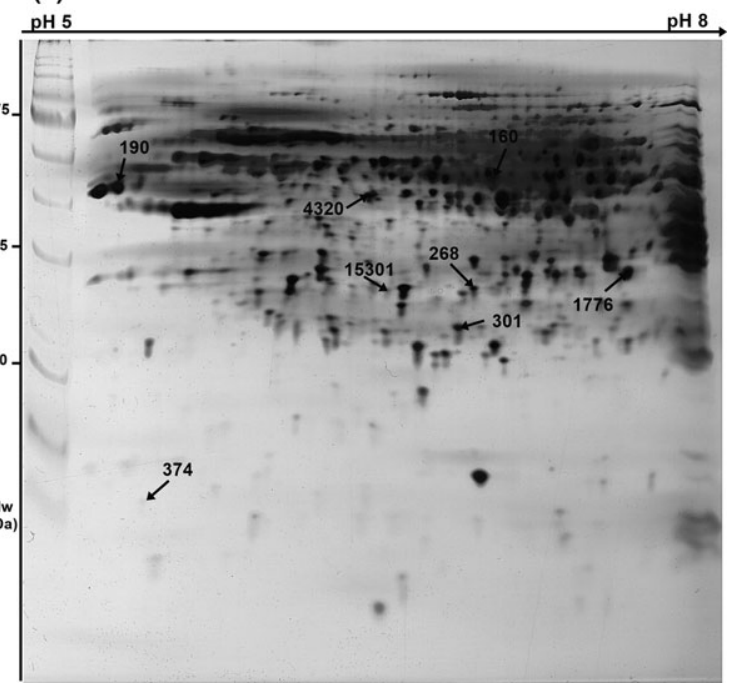

Fig. 1 (a) Representative 2-D PAGE image of chicken liver of control group, proteins with higher expression, compared to nano-Se supplementation, are marked with numbers. (b) Representative 2-D PAGE image of chicken liver of nano-Se supplemented group, proteins with higher expression, compared to control, are marked with numbers.

Spot 190 have shown a 2.4-fold up-regulation in the nano-Se supplemented group and was identified as cytoplasmic actin which is a major constituent of cytoskeleton and has a key role in transport, signalling pathways, cell division, cell motility, etc. (Small et al., 1999).

Proteasome subunit alpha protein was identified in spot 268 showing a 1.4-fold higher expression as a response to the administration of the increased Se doses. The proteasome is a proteinase complex, which degrades those damaged or unneeded proteins in cytoplasm which have a polyubiquitin tag (Glickman and Ciechanover, 2002). The proteasomal degradation pathway is essential, and beside removing the unfunctional proteins, it has regulatory functions having role in the cell cycle, response to oxidative stress and the regulation of gene expression (Köhler et al., 2001; Jung et al., 2009; Murata et al., 2009).

Peroxiredoxin-6, a bifunctional enzyme with glutathione peroxidase and phospholipase A2 activities (Fisher, 2011), was identified in spot 301 showing a 1.2-fold higher expression in nano-Se supplemented group. The peroxiredoxins can control cytokineinduced peroxide levels and can have a role in the signalling pathways (Rhee et al., 2005). Peroxiredoxin-6 is not a selenium-dependent enzyme, in contrast to other peroxiredoxins from the Prdx family (Kang et al., 1998), but it was shown that oxidative stress increases its expression (Kim et al., 2003).

The highest fold change (4.8-fold) upon Se treatment was observed in case of spot 374 . The identified actin-binding protein, the actin depolymerizing factor (ADF), is a microfilament-associated protein and functions as a regulator of cytoskeletal actin turnover. The human counterpart, the coactosin-like protein (Q14019), was shown to be a chaperon of 5-lipoxigenase, the enzyme which regulates leukotriene biosynthesis (Rakonjac et al., 2006).

There are several isoenzymes of malate dehydrogenases; the most important types are the cytoplasmic and the mitochondrial. The mitochondrial variant is one of the key enzymes of citric acid cycle: it catalyses the oxidation of malate to oxalacetate (Musrati et al., 1998). The cytoplasmic isoenzyme is part of malateaspartate shuttle, catalysing the oxidation of malate to oxalacetate with the reduction of $\mathrm{NAD}^{+}$to $\mathrm{NADH}$ (Minárik et al., 2002). The cytoplasmic malate dehydrogenase identified in spot 1776 showed a 1.3-fold higher expression in nano-Se supplemented group compared to the control group.

The glycolytic enzyme alpha-enolase was identified in spot 4320. The enzyme catalyses the conversion of 2-phosphoglycerate to phosphoenolpyruvate in glycolysis (Peshavaria and Day, 1991). The enolase has three major isoforms: alpha-, beta- and gamma-enolase. Alpha-enolase is expressed in several tissues, and beta-enolase is the muscle-specific enolase, expressed in striated muscle while the gamma-enolase is restricted to the cells of nervous system (Chen and Giblett, 1976). The intensity of protein spot 4320 was $70 \%$ higher in the selenium-treated group than in control. 
Table 1 Differentially expressed proteins $(p<0.05)$ of chicken liver between control and nano-Se supplemented group identified by LC-MS/MS

\begin{tabular}{|c|c|c|c|c|c|c|c|}
\hline Spot & Identified protein & Accession number & Protein family & $\mathrm{N} / \mathrm{C}^{\star}$ & $\mathrm{pl} / \mathrm{Mw}(\mathrm{Da}) \dagger$ & Ratio & p-Value \\
\hline 134 & $\begin{array}{l}\text { Phosphoenolpyruvate } \\
\text { carboxykinase [GTP], } \\
\text { mitochondrial }\end{array}$ & P21642 (Gallus gallus) & & $19 / 39$ & 7.2/71 107 & 0.5 & 0.002 \\
\hline 137 & $\begin{array}{l}\text { Phosphoenolpyruvate } \\
\text { carboxykinase [GTP], } \\
\text { mitochondrial }\end{array}$ & P21642 (Gallus gallus) & & $28 / 59$ & 7.2/71 107 & 0.6 & 0.009 \\
\hline 160 & Uncharacterized protein & E1C4W4 (Gallus gallus) & $\begin{array}{l}\text { Aldehyde dehydrogenase } \\
\text { family }\end{array}$ & $15 / 38$ & $7.0 / 58053$ & 2.3 & 0.008 \\
\hline 190 & Actin, cytoplasmic type 5 & P53478 (Gallus gallus) & & $15 / 52$ & $5.3 / 41837$ & 2.4 & 0.003 \\
\hline 231 & $\begin{array}{l}\text { Glycerol-3-phosphate } \\
\text { dehydrogenase [NAD+], } \\
\text { cytoplasmic }\end{array}$ & F1NFY2 (Gallus gallus) & & $21 / 78$ & $6.3 / 38463$ & 0.7 & 0.008 \\
\hline 268 & $\begin{array}{l}\text { Proteasome subunit alpha } \\
\text { type }\end{array}$ & F1NFI8 (Gallus gallus) & & $10 / 43$ & $6.1 / 29322$ & 1.4 & 0.005 \\
\hline 301 & Peroxiredoxin-6 & F1NBV0 (Gallus gallus) & & $19 / 83$ & $6.0 / 25076$ & 1.2 & 0.003 \\
\hline 363 & $\begin{array}{l}\text { Eukaryotic translation } \\
\text { initiation factor 5A-1 }\end{array}$ & Q09121 (Gallus gallus) & & $5 / 22$ & $5.3 / 15889$ & 0.4 & 0.004 \\
\hline 374 & ADF actin-binding protein & C7G537 (Gallus gallus) & & 9/77 & $5.3 / 16106$ & 4.8 & 0.000 \\
\hline 1776 & $\begin{array}{l}\text { Malate dehydrogenase, } \\
\text { cytoplasmic }\end{array}$ & Q5ZME2 (Gallus gallus) & & $15 / 55$ & $6.9 / 36543$ & 1.3 & 0.008 \\
\hline 4320 & Alpha-enolase & F1NZ78 (Gallus gallus) & & $21 / 53$ & $6.4 / 47333$ & 1.7 & 0.015 \\
\hline 6069 & $\begin{array}{l}\text { Uncharacterized protein } \\
\text { (Fragment) }\end{array}$ & F1NEF6 (Gallus gallus) & $\begin{array}{l}\text { Acyl-CoA dehydrogenase } \\
\text { family }\end{array}$ & $24 / 40$ & $7.2 / 67807$ & 0.6 & 0.007 \\
\hline 15301 & Sulfurtransferase & E1C8D8 (Gallus gallus) & & $12 / 55$ & $5.8 / 33221$ & 1.3 & 0.015 \\
\hline
\end{tabular}

*Number of matched peptides/sequence coverage percentage (\%).

$\uparrow$ Theoretical isoelectric point and molecular weight.

$\$$ Ratio of the protein expression of nano-Se supplemented group compared to the control group.

The sulfurtransferase protein (in spot 15301) localized in mitochondria showed 1.3-fold higher expression in nano-Se supplemented group. This enzyme catalyses the production of pyruvate and thyocianate from 3-mercaptopyruvate and cyanide (Vachek and Wood, 1972). It can be considered as an antioxidant enzyme because the harmful cyanide is transformed into less toxic thyocianate. The sulfurtransferase is able to bind and transport selenium and plays role in cysteine metabolism, as well (Ogasawara et al., 2005).

\section{Down-regulated proteins in the nano-Se supplemented} group

The intensity of five spots was lower in the nano-Se supplemented group compared to control group (Fig. 2).

Spots 134 and 137 were both identified as mitochondrial phosphoenolpyruvate carboxykinase (PEPCK-M). These two spots are located at different pI positions, which might be the consequence of post-translational modifications influencing the charge of the proteins, such as the often observed acetylation, malonylation or succinylation widely used for the regulation of metabolic enzymes (Hirschey and Zhao, 2015). The expressions of both spots were reduced by almost half $(0.5$ and 0.6 respectively) in the Se-treated group. The phosphoenolpyruvate carboxykinase protein is an enzyme which catalyses the phosphoenolpyruvate synthesis from oxalacetate in gluconeogenesis (Delbaere et al., 2004). Two isoforms of PEPCK exist in all eukaryotes, the cytosolic and mitochondrial, but in the liver of birds, only the mitochondrial isoform is expressed to recycle the lactate in gluconeogenesis. In birds, the primary gluconeogenic organ is the kidney, which generates glucose from pyruvate and amino acids (Watford et al., 1981; Yang et al., 2009).

Protein spot 231 was identified as cytoplasmic glycerol-3-phosphate-dehydrogenase. This enzyme takes part in both carbohydrate metabolism and fatty acid metabolism: during triglyceride synthesis, the activated fatty acids bind to glycerol-3-phosphate, while in the carbohydrate metabolism, they catalyses the dihydroxyacetone phosphate - glycerol-3-phosphate conversion in the glycerol-3-phosphate shuttle (Harding et al., 1975). Expression of glycerol-3-phos- 
The up-regulated protein spots in nano-Se supplemented group
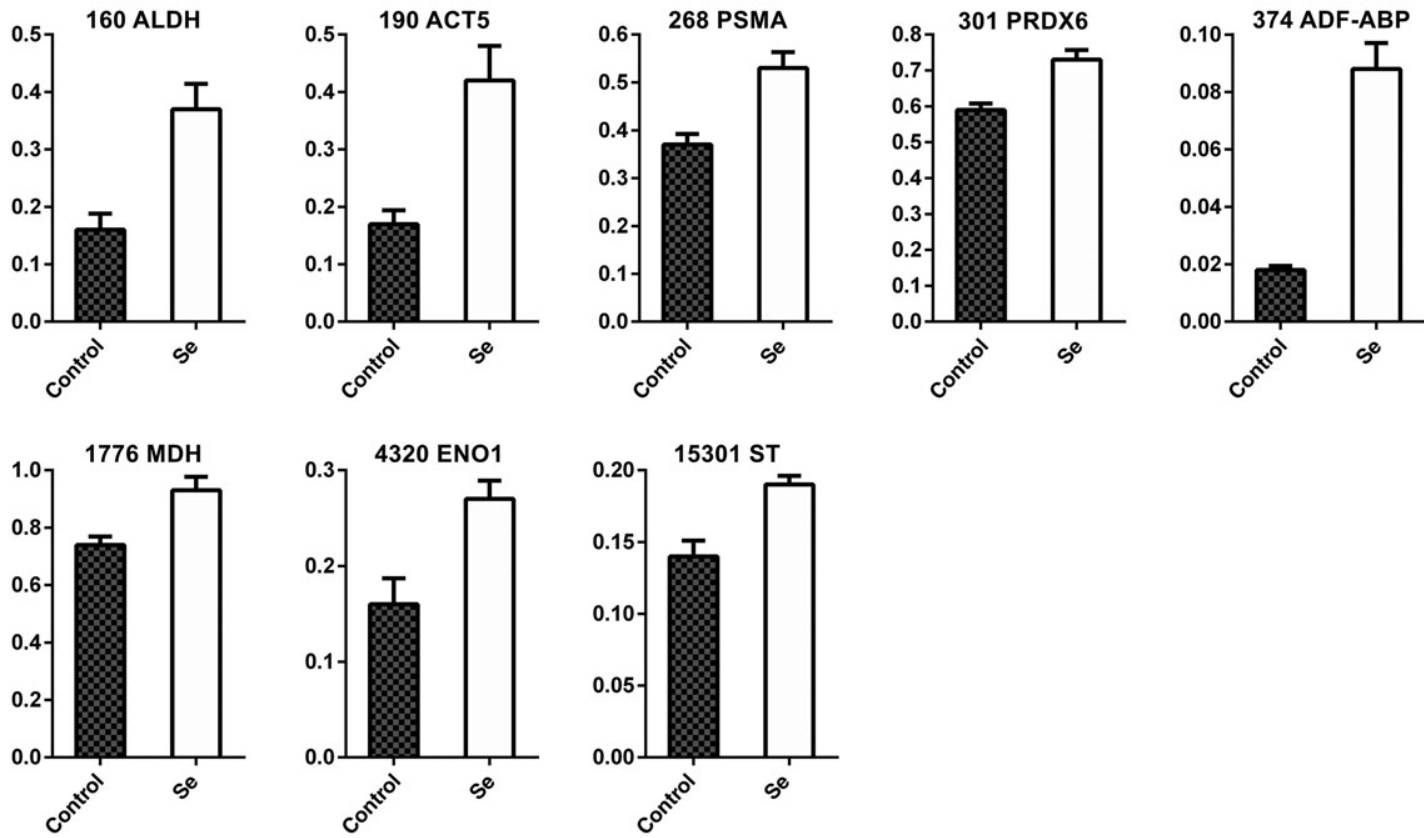

The down-regulated protein spots in nano-Se supplemented group
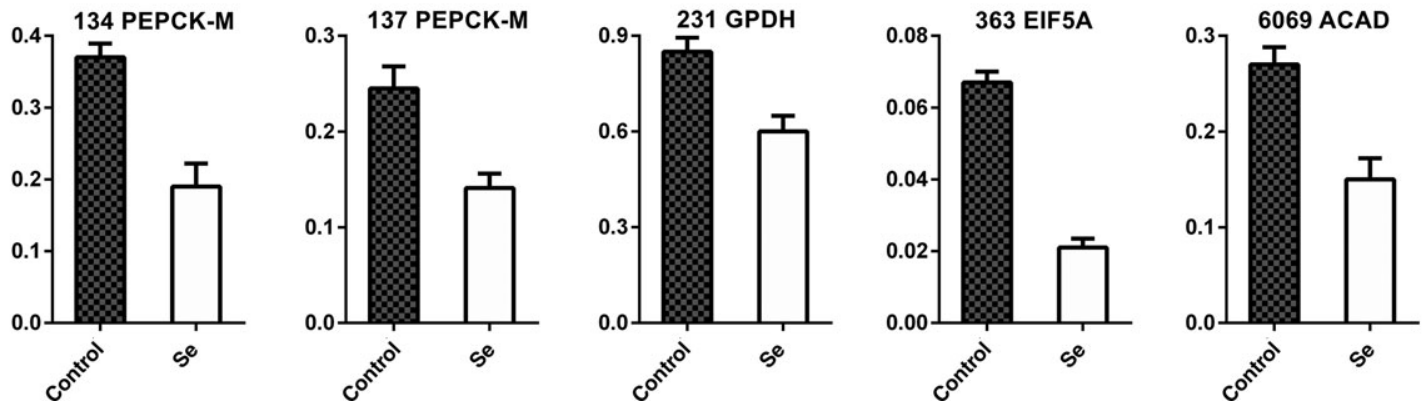

Fig. 2 Normalized volumes $(\mathrm{V} \%)$ of differentially expressed spots $(p<0.05)$ of control and nano-Se supplemented group. Data are presented as mean \pm SEM

phate-dehydrogenase was decreased with $40 \%$ upon nano-Se supplementation.

The eukaryotic translation initiation factor $5 \mathrm{~A}-1$ identified in spot 363 had a 0.4-fold-change difference in its expression between the two groups. This protein binds to mRNA in the initial step of the translation and is present during elongation, helping the binding of small and large ribosomal subunits and activating the GTP-ase activity of eukaryotic initiation factor 2 (Hir et al., 2001).

Spot 6069 was identified as "uncharacterized protein' in the Uniprot database. The protein belongs to acyl-coenzyme A dehydrogenase family, whose members catalyse the first step of beta oxidation of fatty acids in mitochondria using FAD as a cofactor (Thorpe and Kim, 1995). Expression of the protein in spot 6069 was lower by nearly half in the nano-Se supplemented group compared to control group, indicating a marked decrease in beta oxidation upon Se treatment.

\section{Discussion}

The aim of the present study was to compare liver proteome profiles of broilers fed with a control diet without Se supplementation and a diet supplemented with $4.25 \mathrm{mg} / \mathrm{kg}$ DM nano-Se. Our results indicate that liver cells were exposed to a dietary stress caused by the high dose of selenium supplement in the feed. The cellular stress response (CSR) counteracts the stress-induced damages of macromolecules in response to environ- 
mental stressors. It is a universal mechanism; many aspects of CSR does not depend on the type of stressor. Common features of stress induced by different stressors are the deformation and damage of macromolecules, the alterations of the functional threedimensional structure of proteins and the change in cellular redox potential (Pastori and Foyer, 2002; Kültz, 2003). All cellular organisms have a minimal stress proteome, which can take part and control the key mechanisms of cellular stress response (Kültz, 2005). These stress proteins play a role in redox regulation, lipid metabolism, energy metabolism, protein degradation, chaperoning and repair, and DNA damage sensing and repair as well (Kültz, 2003). There are several hypotheses how high dose of selenium can cause stress response and toxicity. One of them is that selenium has a pro-oxidant ability to catalyse the oxidation of thiols and to generate superoxide, which cause oxidative stress (Spallholz, 1994; Spallholz and Hoffman, 2002). Usually, stressors rapidly activate the synthesis of stress proteins. We expected that the level of heat shock proteins (Hsps), especially of Hsp70 are higher in nano-Se supplemented group, but no such change could be observed. Previous studies have demonstrated that the selenium supplemented diet decreased the mRNA level of Hsp70 in piglets and chicken under heat stress (Mahmoud and Edens, 2003; Gan et al., 2013). Gorman et al. (1999) have observed that some antioxidants suppress the Hsps induction on protein level.

Dietary nano-Se supplementation improves the glutathione peroxidase activities in liver, muscle and serum, as well (Leeson et al., 2008; Zhou and Wang, 2011; Cai et al., 2012). Nevertheless, high selenium dose may have a negative effect on the antioxidant capacity, as Cai et al. (2012) have demonstrated that supplementing 0.3 to $0.5 \mathrm{mg} / \mathrm{kg}$ nano-Se improved the oxidation resistance, including glutathione peroxidase activity, but when the nano-Se supplementation reached $2.0 \mathrm{mg} / \mathrm{kg}$, the glutathione peroxidase activity decreased in liver, and its low activity was similar to the activity of control group without nano-Se supplementation. In our study, we did not detect any changes in the expression of glutathione peroxidase between control and nano-Se supplemented $(4.25 \mathrm{mg} / \mathrm{kg})$ chickens.

The biological effect of selenium is ambivalent: lack of Se can lead to the development of diseases (e.g. exudative diathesis, ascites, encephalomalacia in chicken) (Cantor et al., 1975; Walton et al., 1999; Taghizadeh et al., 2012), and nevertheless, the overdose can cause poisoning. The overdose of selenium can damage the antioxidant system, the activity of gluthatione peroxidase reduces and hence. The lipid peroxidation increases, which may be resulted in cell death (Mezes and Salyi, 1994). The expression of three enzymes having antioxidant functions was higher in the nano-Se supplemented group; none of them are among the well-known selenium-dependent enzymes. Alpha-aminoadipic semialdehyde dehydrogenase metabolizes the aldehydes, which are produced in the termination phase of lipid peroxidation (Fong et al., 2006), free radicals, which might be caused by high selenium dose (Stohs and Bagchi, 1995) and generate lipid peroxidation (Yin et al., 2011). The peroxiredoxin- 6 reduces the hydrogen peroxide and phospholipid hydroperoxide and has PLA2 activity (Chae et al., 1994; Fisher, 2011), while the sulfurtransferase transforms the harmful cyanide ion to thiocyanate and is able to bind and transport selenium (Ogasawara et al., 2005). Most probably, the level of these enzymes became higher as a response to the stress induced by the administration of Se-rich diet.

The lower eukaryotic translation initiation factor $5 \mathrm{~A}-1$, which is a significant member of protein synthesis pathway (Jackson et al., 2010), and the higher proteasome alpha subunit level in the nano-Se supplemented group can indicate an increased cellular stress accompanied by decreased protein synthesis and increased protein degradation (Flick and Kaiser, 2012).

The highest difference in the expression levels upon nano-Se treatment has been detected in case of ADF actin-binding protein (4.8-fold change) and cytoskeletal actin (2.4-fold change). No direct evidence was found in the scientific literature whether the selenium influences the expression of actin and actin-binding proteins. It was observed that selenium-binding protein helps to connect actin monomers that can be an indirect evidence for the relation between selenium and actin (Miyaguchi, 2004). Because of the high dose of selenium added to the feed, liver cells were exposed to stress. When cells are exposed to stress, cytoskeletal networks respond with modifications: disassembly of microtubules, collapse of intermediate filaments and disorganization of actin filaments (Liang and MacRae, 1997), and these molecular processes could proceed in livers of our nano-Se supplemented chickens, which might cause the higher ADF/cofilin expression level.

The high level of dietary selenium seems to affect the metabolism of fatty acids and carbohydrates as well; the expression of glycerol-3-phosphate dehydrogenase, phosphoenolpyruvate carboxykinase and acyl-coenzyme A dehydrogenase was reduced as a response to the excess of Se, while the levels of alphaenolase and malate dehydrogenase were higher.

In conclusion, our results revealed that excess selenium supplementation produced a stress reaction at cellular level altering the carbohydrate and fatty acid 
metabolism, increasing the expression of members of the antioxidant system and modifying the protein metabolism by decreasing the protein synthesis and increasing the proteosomal protein degradation. In the same time, the dynamics of the cytoskeletal rearrangements might be changed indicated by the elevated levels of actin and actin-binding proteins.

\section{Acknowledgement}

This work was supported in part by the TÁMOP4.2.2.D-15/1/KONV-2015-0016 project implemented through the New Széchenyi Plan co-financed by the European Social Fund.

\section{References}

Brocker, C.; Lassen, N.; Estey, T.; Pappa,

A.; Cantore, M.; Orlova, V. V.; Chavakis,

T.; Kavanagh, K. L.; Oppermann, U.;

Vasiliou, V., 2010: Aldehyde dehydrogenase 7Al (ALDH7Al) is a novel enzyme involved in cellular defense against hyperosmotic stress. Journal of Biological Chemistry 285, 18452-18463.

Cai, S. J.; Wu, C. X.; Gong, L. M.; Song, T.; Wu, H.; Zhang, L. Y., 2012: Effects of nano-selenium on performance, meat quality, immune function, oxidation resistance, and tissue selenium content in broilers. Poultry Science 91, 25322539.

Cantor, A. H.; Scott, M. L.; Noguchi, T., 1975: Biological availability of selenium in feed stuffs and selenium compounds for prevention of exudative diathesis in chicks. Journal of Nutrition 105, 96-105.

Chae, H. Z.; Robison, K.; Poole, L. B.; Church, G.; Storz, G.; Rhee, S. G., 1994: Cloning and sequencing of thiol-specific antioxidant from mammalian brain: alkyl hydroperoxide reductase and thiol-specific antioxidant define a large family of antioxidant enzymes. Proceedings of National Academy of Sciences 91, 7017-7021.

Chen, S. H.; Giblett, E. R., 1976: Enolase: human tissue distribution and evidence for three different loci. Annals of Human Genetics 39, 277-280.

Chen, G.; Wu, J.; Li, C., 2014: Effect of different selenium sources on production performance and biochemical parameters of broilers. Journal of Animal Physiology and Animal Nutrition 98, 747-754.

Delbaere, L. T.; Sudom, A. M.; Prasad, L.; Leduc, Y.; Goldie, H., 2004: Structure/ function studies of phosphoryl transfer by phosphoenolpyruvate carboxykinase. Biochimica et Biophysica Acta 1697, 271-278.

Dyballa, N.; Metzger, S., 2009: Fast and sensitive Colloidal Coomassie G-250 staining for proteins in polyacrilamide gels. Journal of Visualized Experiments 30 , 1431.
Eszenyi, P.; Sztrik, A.; Babka, B.; Prokisch, J., 2011: Elemental, nano-sized (100$500 \mathrm{~nm}$ ) selenium production by probiotic lactic acid bacteria. International Journal of Bioscience, Biochemistry and Bioinformatics 1, 148-152.

Fisher, A. B., 2011: Peroxiredoxin 6: a bifunctional enzyme with glutathione peroxidase and phospholipase A2 activities. Antioxidants $\theta$ Redox Signaling 15, 831-844.

Fisinin, V. I.; Papazyan, T. T.; Surai, P. F., 2009: Producing selenium-enriched eggs and meat to improve the selenium status of the general population. Critical Reviews in Biotechnology 29, 18-28.

Flick, K.; Kaiser, P., 2012: Protein degradation and the stress response. Seminars in Cell $\theta$ Developmental Biology 23, 515-522.

Fong, W. P.; Cheng, C. H. K.; Tang, W. K., 2006: Antiquitin, a relatively unexplored member in the superfamily of aldehyde dehydrogenases with diversified physiological functions. Cellular and Molecular Life Sciences 63, 2881-2885.

Gan, F.; Ren, F.; Chen, X.; Lv, C.; Pan, C.; Ye, G.; Shi, J.; Shi, X.; Zhou, H.; Shituleni, A.; Huang, K., 2013: Effects of selenium-enriched probiotics on heat shock protein mRNA levels in piglet under heat stress conditions. Journal of Agricultural and Food Chemistry 61, 2385-2391.

Glickman, M. H.; Ciechanover, A., 2002: The ubiquitin-proteasome proteolytic pathway: destruction for the sake of construction physiological. Physiological Reviews 82, 373-428.

Gorman, A. M.; Heavey, B.; Creagh, E.; Cotter, T. G.; Samali, A., 1999: Antioxidant-mediated inhibition of the heat shock response leads to apoptosis. FEBS Letters 445, 98-102.

Harding, J.W. Jr; Pyeritz, E.A.; Copeland, E.S.; Harold, B., 1975: Role of glycerol 3-phosphate dehydrogenase in glyceride metabolism - effect of diet on enzyme activities in chicken liver. Biochemical Journal 146, 223-229.

Hir, H. L.; Gatfield, D.; Izaurralde, E.; Moore, M. J., 2001: The exon-exon junction complex provides a binding platform for factors involved in mRNA export and nonsense mediated mRNA decay. EMBO Journal 20, 4987-4997.

Hirschey, M. D.; Zhao, Y., 2015: Metabolic regulation by lysine malonylation, succinylation and glutarylation. Molecular and Cellular Proteomics 110, 1431-1440.

Jackson, R. J.; Hellen, C. U. T.; Pestova, T. V., 2010: The mechanism of eukaryotic translation initiation and principles of its regulation. Nature Reviews Molecular Cell Biology 11, 113-127.

Jung, T.; Catalgol, B.; Grune, T., 2009: The proteasomal system. Molecular Aspects of Medicine 30, 191-296.

Kang, S. W.; Baines, I. C.; Rhee, S. G., 1998: Characterization of a mammalian peroxiredoxin that contains one conserved cysteine. Journal of Biological Chemistry 273, 6303-6311.

Kim, H. S.; Manevich, Y.; Feinstein, S. I.; Pak, J. H.; Ho, Y. S.; Fisher, A. B., 2003: Induction of 1 -cys peroxiredoxin expression by oxidative stress in lung epithelial cells. American Journal of Physiology Lung Cellular Molecular Physiology 285, 363-369.

Köhler, A.; Bajorek, M.; Groll, M.; Moroder, L.; Rubin, D. M.; Huber, R.; Glickman, M. H.; Finley, D., 2001: The substrate translocation channel of the proteasome. Biochimie 83, 325-332.

Köhrle, J., 2004: Selenium in biology and medicine-further progress and increasing interest. Journal of Trace Elements in Medicine Biology 18, 61-63.

Kültz, D., 2003: Evolution of the cellular stress proteome: from monophyletic origin to ubiquitous function. The Journal of Experimental Biology 206, 3119 3124.

Kültz, D., 2005: Molecular and evolutionary basis of the cellular stress response. Annual Review of Physiology 67, 225-257.

Leeson, S. H.; Namkung, L.; Caston, S.; Durosoy, P.; Schlegel, P., 2008: Comparison of selenium levels and sources and dietary fat quality in diets for broiler breeders and layer hens. Poultry Science 87, 2605-2612. 
Liang, P.; MacRae, T. H., 1997: Molecular chaperones and the cytoskeleton. Journal of Cell Science 110, 1431-1440.

Mahmoud, K. Z.; Edens, F. W., 2003: Influence of selenium sources on agerelated and mild heat stress-related changes of blood and liver glutathione redox cycle in broiler chickens (Gallus domesticus). Comparative Biochemistry and Physiology Part B: Biochemistry and Molecular Biology 136, 921-934.

Mezes, M.; Salyi, G., 1994: Effect of acute selenium toxicosis on the lipid peroxide status and the glutathione system of broiler chickens. Acta Veterinaria Hungarica 42, 459-463.

Minárik, P.; Tomásková, N.; Kollárová, M.; Antalík, M., 2002: Malate dehydrogenases - structure and function. General Physiology and Biophysics 21, 257265.

Miyaguchi, K., 2004: Localization of selenium-binding protein at the tips of rapidly extending protrusions. Histochemistry and Cell Biology 121, 371376.

Murata, S.; Yashiroda, H.; Tanaka, K. 2009: Molecular mechanisms of proteasome assembly. Nature Reviews Molecular Cell Biology 10, 104-115.

Musrati, R. A.; Kollárová, M.; Mernik, N.; Mikulásová, D., 1998: Malate dehydrogenase: distribution, function and properties. General Physiology and Biophysics 17, 193-210.

Ogasawara, Y.; Lacourciere, G. M.; Ishii, K.; Stadtman, T. C., 2005: Characterization of potential selenium-binding proteins in the selenophosphate synthetase system. Proceedings of the National Academy of Sciences 102, 1012-1016.

Oremland, R. S.; Herbel, M. J.; Blum, J. S.; Langley, S.; Beveridge, T. J.; Ajayan, P. M.; Sutto, T.; Ellis, A. V.; Curran, S., 2004: Structural and spectral features of selenium nanospheres produced by Serespiring bacteria. Applied and Environmental Microbiology 70, 52-60.

Pappas, A. C.; Acamovic, T.; Sparks, N. H.; Surai, P. F.; McDevitt, R. M., 2006: Effects of supplementing broiler breeder diets with organoselenium compounds and polyunsaturated fatty acids on hatchability. Poultry Science 85, 15841593.

Pastori, G. M.; Foyer, C. H., 2002: Common components, networks, and pathways of cross-tolerance to stress: the central role of "redox" and abscisic acid- mediated controls. Plant Physiology $\mathbf{1 2 9}$, 460-468.

Payne, R. L.; Southern, L. L., 2005: Comparison of inorganic and organic selenium sources for broilers. Poultry Science 84, 898-902.

Peshavaria, M.; Day, I. N., 1991: Molecular structure of the human muscle-specific enolase gene (ENO3). Biochemical Journal 275, 427-433.

Prokisch, J.; Zommara, M.A., 2010: Process for Producing Elemental Selenium Nanospheres, United States Patent 20100189634.

Rakonjac, M.; Fischer, L.; Provost, P.; Werz, O.; Steinhilber, D.; Samuelsson, B.; Radmark, O., 2006: Coactosin-like protein supports 5-lipoxygenase enzyme activity and up-regulates leukotriene A4 production. Proceedings of the National Academy of Sciences 103, 13150-13155.

Rhee, S.; Chae, H.; Kim, K., 2005: Peroxiredoxins: a historical overview and speculative preview of novel mechanisms and emerging concepts in cell signaling. Free Radical Biology $\vartheta$ Medicine 38 1543-1552.

Rotruck, J. T.; Pope, A. L.; Ganther, H. E.; Swanson, A. B.; Hafeman, D. G.; Hoekstra, W. G., 1973: Selenium: biochemical role as a component of glutathione peroxidase. Science 179, 588-590.

Small, J. V.; Rottner, K.; Kaverina, I., 1999: Functional design in the actin cytoskeleton. Current Opinion in Cell Biology $11,54-60$.

Spallholz, J. E., 1994: On the nature of selenium toxicity and carcinostatic activity. Free Radical Biology and Medicine 17, 45-64.

Spallholz, J. E.; Hoffman, D. J., 2002: Selenium toxicity: cause and effects in aquatic birds. Aquatic Toxicology 57, 227-237.

Stohs, S. J.; Bagchi, D., 1995: Oxidative mechanisms in the toxicity of metal ions. Free Radical Biology Medicine 18, 321-336.

Surai, P. F., 2006: Selenium in Nutrition and Health. Nottingham University Press, Nottingham, UK.

Szabo, Z.; Szeline Szomor, J.; Foeldi, I.; Janaky, T., 2012: Mass spectrometrybased label free quantification of gel separated proteins. Journal of Proteomics 75, 5544-5553.

Taghizadeh, A.; Zakeri, A.; Rezapour, A., 2012: Comparative effect of vitamin $\mathrm{E}$ and vitamin E-selenium compound on
T4-induced ascites syndrome (By T4suplementation of the Diet) in broiler chickens. Global Veterinaria 9, 262-265.

Thorpe, C.; Kim, J. J., 1995: Structure and mechanism of action of the acyl-CoA dehydrogenases. FASEB Journal 9, 718725.

Tinggi, U., 2003: Essentiality and toxicity of selenium and its status in Australia: a review. Toxicology Letters 137, 103-110.

Vachek, H.; Wood, J. L., 1972: Purification and properties of mercaptopyruvate sulfur transferase of Escherichia coli. Biochimica et Biophysica Acta 258, 133146.

Van Cauwenbergh, R. V.; Robberectht, H.; Va Vlaslaer, V., 2004: Comparison of the serum selenium content of healthy adults living in the Antwerp region (Belgium) with recent literature data. Journal of Trace Elements in Medicine and Biology 18, 99-112.

Walton, J. P. J. M.; Bond, R.; Julian, J.; Squires, E. J., 1999: Effect of dietary flax oil and hypobaric hypoxia on pulmonary hypertension and haematological variables in broiler chickens. British Poultry Science 44, 385-391.

Wang, H.; Zhang, J.; Yu, H., 2007: Elemental selenium at nano size possesses lower toxicity without compromising the fundamental effect on selenoenzymes: comparison with selenomethionine in mice. Free Radical Biology $\theta$ Medicine 42, 1524-1533.

Watanabe, T.; Kiron, V.; Satoh, S., 1997: Trace minerals in fish nutrition. Aquaculture 151, 185-207.

Watford, M.; Hod, Y.; Chiao, Y. B.; Utter, M. F.; Hanson, R. W., 1981: The unique role of the kidney in gluconeogenesis in the chicken. The Journal of Biological Chemistry 256, 10023-10027.

Yang, J.; Satish, C. K.; Hanson, R. W., 2009: What is the metabolic role of phosphoenolpyruvate carboxykinase? Journal of Biological Chemistry 284, 27025-27029.

Yin, H.; Xu, L.; Porter, N. A., 2011: Free radical lipid peroxidation: mechanisms and analysis. Chemical Reviews 111 , 5944-5972.

Zhou, X.; Wang, Y., 2011: Influence of dietary nano elemental selenium on growth performance, tissue selenium distribution, meat quality, and glutathione peroxidase activity in Guangxi Yellow chicken. Poultry Science 90, 680686. 